\title{
Growth, production and wood quality in integrated crop-livestock-forest and monoculture systems
}

\author{
Mayra Daniela Ferreira ${ }^{1} \oplus$, Rafael Rodolfo de Melo $^{2} \oplus$, Hélio Tonini ${ }^{3} \odot$, Diego Martins Stangerlin ${ }^{4} \odot$, \\ Rafael Beltrame ${ }^{5}{ }^{\circledR}$, Darci Alberto Gatto ${ }^{5}{ }^{\oplus}$, Adriano Reis Prazeres Mascarenhas ${ }^{6} \mathbb{0}$

\footnotetext{
1 Universidade Federal de Mato Grosso, Programa de Pós-Graduação em Ciências Florestais e Ambientais, Cuiabá, MT, Brasil. E-mail: mayradaniela90@gmail.com

2 Universidade Federal Rural do Semi-Árido, Mossoró, RN, Brasil. E-mail: rafael.melo@ufersa.edu.br

${ }^{3}$ Embrapa Pecuária Sul, Bagé, RS, Brasil. E-mail: helio.tonini@embrapa.br

4 Universidade Federal de Mato Grosso, Instituto de Ciências Agrárias e Ambientais, Sinop, MT, Brasil. E-mail: diego_stangerlin@yahoo.com.br

${ }^{5}$ Universidade Federal de Pelotas, Pelotas, RS, Brasil. E-mail: beltrame.rafael@yahoo.com.br; darcigatto@yahoo.com

${ }^{6}$ Fundação Universidade Federal de Rondônia, Departamento Acadêmico de Engenharia Florestal, Rolim Moura, RO, Brasil. E-mail: adriano.mascarenhas@unir.br
}

ABSTRACT: This work aimed to evaluate the growth, production and wood quality a clonal hybrid (Eucalyptus grandis $x$ Eucalyptus urophylla) produced in integrated crop-livestock-forest systems (iCLF) and monoculture. The study was carried out in an iCLF system and a monoculture stand, both in the municipality of Sinop, state of Mato Grosso, Brazil. Diameter (at $1.3 \mathrm{~m}$ height), total height and production (volume) of trees were evaluated, along with wood quality (growth strains and wood density). The parameters of the trees in the iCLF system were analyzed according to the different positions of the trees in the plantation (lines and between rows), and were compared with the quality of the wood produced in the traditional system (homogeneous plantation). The results indicated an approximate yield of $22.98 \mathrm{~m}^{-3} \mathrm{ha}^{-1}$ year $^{-1}$ for ICLF and $32.15 \mathrm{~m}^{-3} \mathrm{ha}^{-1}$ year ${ }^{-1}$ for traditional planting. The longitudinal residual deformation LRD (growth stress) in the iCLF system was higher for the central trees of the stand. The canopy projection in monoculture plantation and the central line of the iCLF system presented more homogenous distribution in relation to the other planting lines. The trees produced in the integrated system presented greater wood density than those produced in the monoculture.

Key words: non-destructive analysis; wood quality; agroforestry systems

\section{Crescimento, produção e qualidade da madeira em sistemas de integração lavoura-pecuária-floresta e monocultivo}

RESUMO: O trabalho teve como objetivo avaliar o crescimento, a produção e a qualidade da madeira do híbrido clonal (Eucalyptus grandis x Eucalyptus urophylla) produzido em sistemas de integração lavoura-pecuária-floresta (iLPF) cultivado em renque triplo e, monocultivo produzido em espaçamento de $3,50 \times 3,00 \mathrm{~m}$. O estudo foi desenvolvido em um sistema iLPF e em um monocultivo, ambos planejados no município de Sinop-MT. Foi avaliado o crescimento em diâmetro a 1,3 m de altura e altura total, a produção (volume) e a qualidade da madeira (tensões de crescimento e a densidade da madeira) através de técnicas não destrutivas. A análise destes parâmetros foi em função das diferentes posições das árvores nos plantios (linhas e entre linhas do plantio no renque), e comparada à qualidade da madeira produzida pelo sistema tradicional (plantios homogêneos). No sistema iLPF a produtividade foi estimada em $22,98 \mathrm{~m}^{-3} \mathrm{ha}^{-1}$ ano-1 $^{-1}$ e no monocultivo $32,15 \mathrm{~m}^{-3} \mathrm{ha}^{-1}$ ano-1 $^{-1}$. Nos resultados da deformação residual longitudinal - DRL (tensões de crescimento), verificou-se para o sistema iLPF maior deformação nas árvores centrais do renque. A projeção de copa dentro do plantio homogêneo e na linha central do sistema iLPF apresentou distribuição mais homogênea em relação as demais linhas do plantio. As árvores produzidas no sistema iLPF apresentam densidade da madeira superior àquelas produzidas no monocultivo.

Palavras-chave: análise não-destrutiva; qualidade da madeira; sistemas agroflorestais 


\section{Introduction}

The integrated crop-livestock-forest (iCLF) system intensifies land use by producing grains, forage plants, livestock, wood and non-wood products in the same area (Balbino et al., 2011). These systems have been expanding due to the possibility of diversifying activities, reducing costs and increasing income of farmers (Alvarenga et al., 2010), in addition to presenting high potential for recovery of degraded areas (Oliveira et al., 2015; Mascarenhas et al., 2017).

Among the tree species used in commercial plantations with potential for use in the iCLF system, species of the genus Eucalyptus stand out for fast growth, genetic improvement through advanced technologies and research related to management (Lucas et al., 2015) and various uses of wood, such as firewood, charcoal, fence posts, pulp and paper, fiber and particle boards, construction of houses and furniture (Pereira, 2000; Oliveira et al., 2015).

However, although Eucalyptus has numerous attributes for timber purposes, there are limitations imposed by growth stresses, which are very common (Beltrame et al., 2012). These growth stresses are the result of the internal forces that act on the tissues of the trees, in order to keep them intact and erect. However, the high levels of growth stresses in the tree cause low yield in the production of sawn wood, due to the high incidence of cracks (Lima et al., 2004).

In integrated production systems, as is the case of iCLF, the atypical conditions to which trees are exposed, such as increased exposure to solar radiation, winds and shock from animals, can reduce the wood quality (Ferreira et al., 2020).

Among the various properties of wood, one of the most used to estimate quality and specify suitability for various uses is density. In view of the many uses of eucalyptus wood and the benefits of iCLF, it is important to study the quality of the wood produced in these production systems to enable correct indications regarding its use.

Nevertheless, due to the delay in harvesting the forest component in this system, techniques are needed that can predict the quality of this wood while trees are alive (nondestructive techniques). The most suitable techniques for this analysis are measurements of growth stresses.

Growth stresses are present in both conifers and hardwood trees. Among the hardwoods, the Eucalyptus species stand out the most, this being one of the main problems in wood processing. This phenomenon is linked to the characteristic fast growth of this genus (Braz et al., 2017).

Thus, the present study aimed to evaluate the growth, production and quality of the wood of the hybrid Eucalyptus grandis $x$ Eucalyptus urophylla grown in an integrated croplivestock-forest (iCLF) system in comparison with the same hybrid trees grown in a monoculture system, both in the state of Mato Grosso.

\section{Material and Methods}

\section{Characterization of the study area}

The study was carried out using an integrated croplivestock-forest system (iCLF) and a monoculture stand, both planned and implemented by Embrapa Agrossilvipastoril in the municipality of Sinop, in the northern region of the state of Mato Grosso ( $11^{\circ} 51^{\prime} 43,74^{\prime \prime} S ; 55^{\circ} 36^{\prime} 2,58^{\prime \prime}$ W). In the region the relief is flat, with average altitudes of $380 \mathrm{~m}$, and predominance of red-yellow Latosol (Gregolin, 2017).

The climate of the region is of the Am type (tropical monsoon), with air temperature ranging from $18{ }^{\circ} \mathrm{C}$ to 32.5 ${ }^{\circ} \mathrm{C}$ and average of $25^{\circ} \mathrm{C}$ (Alvares et al., 2013). The average accumulated precipitation ranges from $2,000 \mathrm{~mm}$ to 2,200 $\mathrm{mm}$, and the average annual relative humidity is $76 \%$, with predominant winds in the north and northeast directions during spring/summer and northeast and southeast during autumn/winter (Alvares et al., 2013; Boton et al., 2013).

\section{Implementation and description of the experiment}

The homogeneous experimental planting was implemented in February 2011 with $3.5 \times 3.0$ m spacing in an area of approximately 10 hectares. In the same year, the iCLF system was implemented, consisting of four rows of triple tree lines with $15 \mathrm{~m}$ between the rows, and $3.0 \times 2.0 \mathrm{~m}$ spacing between trees, in an approximate area of 7.0 hectares.

For the iCLF system, the agricultural components were corn, soybean and cowpea, planted in the first, second and third year, respectively. In the third year, the forage species (Brachiaria brizantha cv. Marandu) was also planted to support the livestock component. From the fourth year onwards, only the forage species was maintained and the livestock component (dairy cattle - crossbred Holstein with gir heifers) was added, characterizing the silvopastoral system.

As a forest component for both areas, clone $\mathrm{H} 13$ was used, a hybrid of Eucalyptus urophylla S. T. Blake x Eucalyptus grandis W. Hill ex Maiden, also known as Eucalyptus urograndis.

\section{Selection of the trees}

For the analysis, 12 five-year-old trees were selected in the monoculture system, with the trees on the edges (three rows) being rejected in the sampling. In the iCLF system, 36 trees were selected, 12 per row, distributed in the central, northern and southern exposures.

This division occurred to assess the influence of the production system (homogeneous or integrated) on the technical quality of the wood. The planting lines forming the row were analyzed separately, considering the three different exposures (Figure 1). In both systems, trees were selected that had straight and cylindrical trunks, no bifurcation and good phytosanitary conditions.

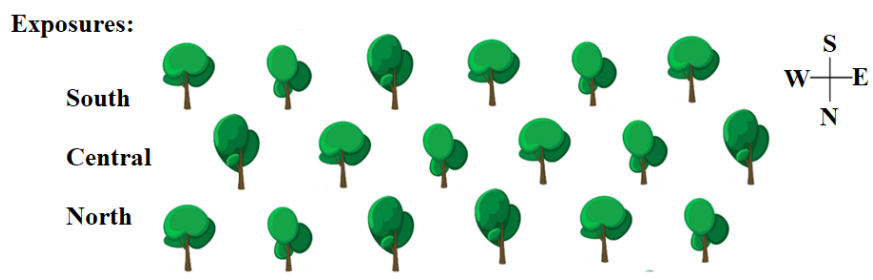

Figure 1. Implementation model of the iCLF system in triple row, with exposure of each of line in different directions. 


\section{Dendrometric variables}

The diameters were measured at height of $1.3 \mathrm{~m}(\mathrm{DBH})$, along with the total height, volume of wood with bark and the canopy projection. The DBH was obtained with a tape measure and the total height was measured with a Vertex III hypsometer. The volume of each tree was estimated means of height, diameter and a shape parameter of 0.50 . The volume estimated per hectare was calculated by multiplying the average volume of the tree by the number of trees per hectare of each of the evaluated systems.

\section{Tree canopy projection}

The canopy projection was assessed with a Lemmon convex spherical densiometer (D), based on the four cardinal points (North, South, East and West). The densiometer consists of a convex mirror divided into 24 squares. For reading, each grid was subdivided into quadrants, and the number of quadrants of the grid reflecting the canopy was counted. The total of the squares was added and multiplied by 1.04 , to obtain the projection estimate in meters (Lemmon, 1957).

\section{Nondestructive analysis - wood density}

The density of the wood was estimated with the help of a Pilodyn density meter, taken at breast height, in four directions according to the cardinal points, after removal of the bark (Figures $2 \mathrm{~A}$ and $2 \mathrm{~B}$ ). The equipment penetrates a
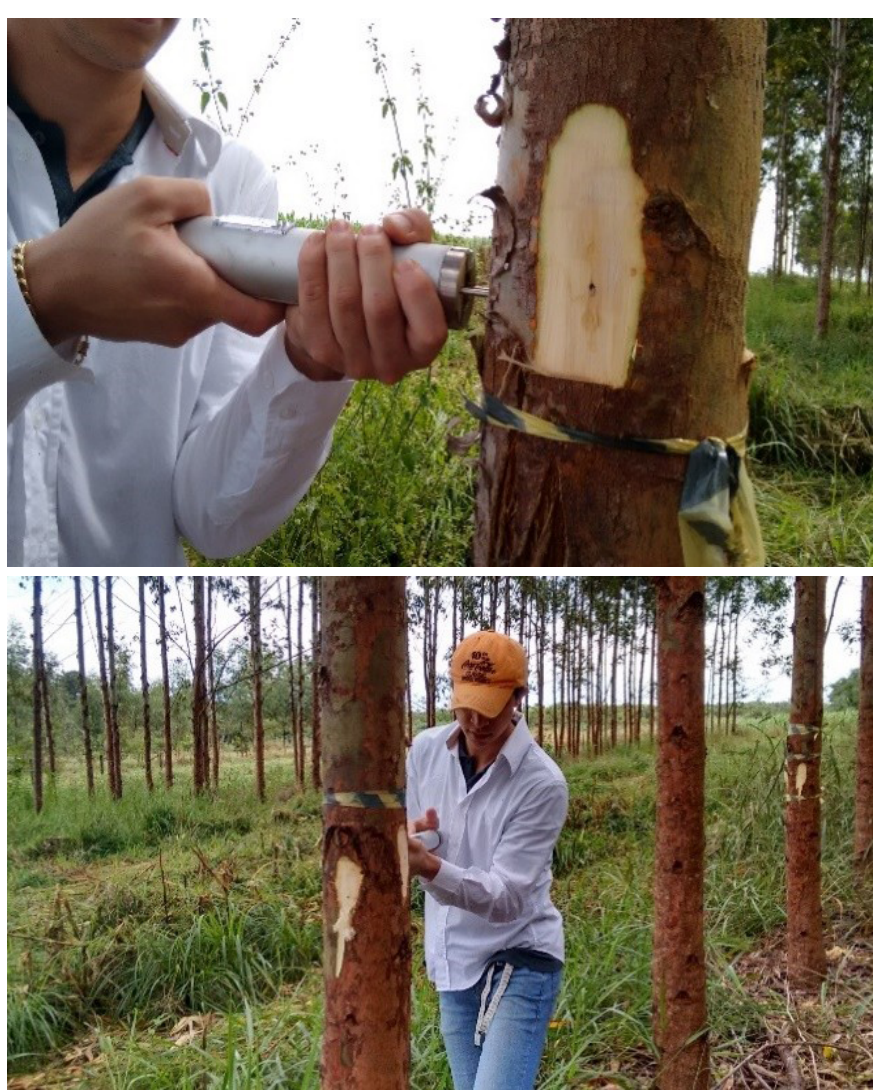

Figure 2. Use of a Pilodyn meter to determine the density of wood from Eucalyptus grandis x Eucalyptus urophylla trees planted at Embrapa Agrossilvipastoril, in Sinop, Mato Grosso, Brazil.
$2.5 \mathrm{~mm}$ diameter needle, driven by a spring with a constant force of 6 joules. In determining the basic density through the use of a Pylodin meter, the balanced equation proposed by Beltrame et al. (2012) is used to validate the effectiveness of the method (Equation 1).

$$
\mathrm{DB}=679.52941-13.52125 \times \mathrm{r}
$$

where: $\mathrm{DB}=$ basic density for each tree, in $\mathrm{kg} \mathrm{m}^{-3} ; \mathrm{r}=$ puncture resistance, recorded on the Pilodyn scale, in $\mathrm{mm}$.

\section{Nondestructive analysis - growth stress}

The growth stresses of the trees were estimated by measuring the longitudinal residual strain (LRS), which is an indirect measure of stresses, obtained with the aid of an extensometer (CIRAD-Fôret method) that provides digital data of this strain in millimeters $(\mathrm{mm})$.

To perform the measurements, as recommended by Beltrame et al. (2012), first the bark of the trunk was removed at breast height. Then two pins spaced $45 \mathrm{~mm}$ apart in the direction of the grain were driven into the tree to attach a digital dial indicator. A $20 \mathrm{~mm}$ hole was made with a hand drill arch in the median position between the pins, where the wood tissues ruptured and the tension recorded by the device was released.

The readings of the LRS were performed in four positions (considering the cardinal points) around the tree trunk, following the orientation of planting to standardize the measurements, as recommended by Muneri et al. (1999).

\section{Statistical analysis}

Statistical comparisons were made for dendrometric variables and nondestructive wood quality tests comparing the iCLF and monoculture systems. Additionally, the different relative positions of the trees were compared between the iCLF lines. The data obtained in the evaluations were subjected to analysis of variance, and for the significant effects of treatment, the Tukey test was applied for comparison of means, at $5 \%$ probability. Before the analysis, the assumptions of normality, homogeneity of variance and data independence were evaluated. The program used for the analyses was the Action supplement, which analyzes the data in Microsoft Excel spreadsheets.

\section{Results and Discussion}

\section{Dendrometric variables}

In the dendrometric analysis, we observed that the trees from the integrated planting presented the best yield, with diameter of $16.77 \mathrm{~cm}$ and total height of $14.74 \mathrm{~m}$, versus diameter of $13.84 \mathrm{~cm}$ and total height of $12.72 \mathrm{~m}$ for the monoculture (Table 1). Similar results were observed by Oliveira et al. (2015), who, when comparing the performance of the same hybrid in iCLF and monoculture systems, found greater height of trees in the integrated system at different ages (13, 18 and 25 months). 
Table 1. Average values of dendrometric variables measured for Eucalyptus grandis $x$ Eucalyptus urophylla trees grown in monoculture and iCLF systems in Sinop, Mato Grosso, Brazil.

\begin{tabular}{ccccc}
\hline System & $\begin{array}{c}\text { DBH } \\
(\mathbf{c m})\end{array}$ & $\begin{array}{c}\text { Ht } \\
(\mathbf{m})\end{array}$ & $\begin{array}{c}\text { V } \\
\left(\mathbf{m}^{\mathbf{3}} \mathbf{h a}^{-1}\right)\end{array}$ & $\begin{array}{c}\text { CAI } \\
\left(\mathbf{m}^{\mathbf{3}} \mathbf{h a}^{-1} \mathrm{ano}^{-1}\right)\end{array}$ \\
\hline Monoculture & $13.84 \pm 1.08 \mathrm{~b}$ & $12.72 \pm 0.79 \mathrm{~b}$ & 91.86 & 22.96 \\
iCLF & $16.77 \pm 1.39 \mathrm{a}$ & $14.74 \pm 1.04 \mathrm{a}$ & 65.66 & 16.42 \\
\hline
\end{tabular}

Where: $\mathrm{DBH}=$ Diameter at breast height, standardized at $1.3 \mathrm{~m} ; \mathrm{Ht}=$ total height; $\mathrm{V}=$ volume projection per hectare for iCLF and homogeneous; $\mathrm{CAI}=\mathrm{current}$ annual increment; Means followed by the same letter in the columns do not differ statistically, according to the Tukey test at $5 \%$ significance.

The values found are similar to those reported by Matias (2016), when analyzing individuals of Eucalyptus grandis $\mathrm{x}$ Eucalyptus urophylla in an integrated system at six years of age. With spacing of $3 \times 2 \mathrm{~m}$, distance between rows of $20 \mathrm{~m}$ and triple lines, average values of $19.06 \mathrm{~cm}$ for $\mathrm{DBH}$ and volume of $0.31 \mathrm{~m}^{3}$ per plant were obtained. The superior performance of the integrated system can be attributed to lower plant density compared to the monoculture stand, due to the spacing between rows, where there is greater availability of resources (soil and nutrients) and less intraspecific competition (Oliveira et al., 2015; Mascarenhas et al., 2017).

When evaluating different spacing of Eucalyptus hybrids, Oliveira et al. (2009) found that the volume varies according to the different spatial arrangements in an agrosilvopastoral system, with differentiation of $\mathrm{DBH}$ and total height. Our results corroborate those.

In the iCLF system, there was no significant difference ( $p>0.05$ ) between the different exposures, for all variables studied. Mean DBH values ranged from 16.27 to $17.44 \mathrm{~cm}$ and total height from 14.63 to $14.78 \mathrm{~m}$ (Table 2).

As for production, the monoculture yielded $128.6 \mathrm{~m}^{3} \mathrm{ha}^{-1}$ while the iCLF system yielded $91.93 \mathrm{~m}^{3} \mathrm{ha}^{-1}$, with average annual increases of $22.98 \mathrm{~m}^{3} \mathrm{ha}^{-1}$ year ${ }^{-1}$ for iCLF and $32.15 \mathrm{~m}^{3}$ $\mathrm{ha}^{-1}$ year $^{-1}$ for traditional planting. This can be attributed to the higher density of plants compared to the iCLF, which is only concentrated in the rows.

Behavior similar to the present study was observed by Oliveira et al. (2015) when comparing the performance of Eucalyptus in monoculture and iCLF systems. Those results corroborated earlier findings by Oliveira et al. (2009), who when

Table 2. Average values of the dendrometric variables measured for the iCLF system of Eucalyptus grandis $\mathrm{x}$ Eucalyptus urophylla in Sinop, Mato Grosso, Brazil.

\begin{tabular}{ccc}
\hline Exposure & $\begin{array}{c}\text { DBH } \\
(\mathbf{c m})^{\text {NS }}\end{array}$ & $\begin{array}{c}\text { Ht } \\
(\mathbf{m})^{\text {NS }}\end{array}$ \\
\hline Central & $16.27 \pm 1.55$ & $14.63 \pm 1.54$ \\
North & $16.59 \pm 1.31$ & $14.81 \pm 0.75$ \\
South & $17.44 \pm 1.11$ & $14.78 \pm 0.71$ \\
\hline
\end{tabular}

Where: $\mathrm{DBH}=$ Diameter at breast height; $\mathrm{Ht}=$ total height; NS: no statistical differences were detected $(p>0.05)$. comparing different types of spacing of a Eucalyptus hybrid, found that the volume was affected by the arrangements.

The canopy projection (measuring the tree canopy radius in four positions according to the exposure in the N, S, E, W directions) in monoculture and iCLF systems, on average, did not show significant difference ( $p>0.05$ ). However, there was variation in the distribution for the four cardinal points (Table 3 ). In the iCLF system, the greatest projection occurred along the North-South axis, while in the homogeneous system there was greater regularity of the projection.

In the iCLF system, the canopy of individuals in each line tended to project towards the side of greatest exposure (North or South), with the exception of the central line. The North line presented average values of $3.24 \mathrm{~m}$ and the South line showed $3.02 \mathrm{~m}$ (Table 4). This result is due to the lower density of trees per unit of cultivated area in the integrated system, which implies greater space for canopy growth, mainly in the lateral lines (Martins et al., 2002; Radomski \& Ribaski, 2010). In the Southern hemisphere, the openings to the North generally receive higher incidence of sunlight throughout the year, which leads to higher metabolic activity of the trees, resulting in greater growth.

\section{Nondestructive analysis - wood density}

In the monoculture stand, the Pilodyn device registered values from 19.75 to $20.92 \mathrm{~mm}$ deep in the bark, while in the integrated system, values from 18.03 to $18.39 \mathrm{~mm}$ were found (Table 5).

Since the estimated density is a variable dependent on Pilodyn penetration, there was a difference between the values of homogeneous planting and the iCLF system ( $p$ $<0.05)$. The values found for homogeneous system ranged from 0.397 to $0.423 \mathrm{~g} \mathrm{~cm}^{-3}$ while in the integrated system the values were from 0.431 to $0.490 \mathrm{~g} \mathrm{~cm}^{-3}$ (Table 6). The density results obtained are similar to those observed by Hsing et al. (2016), who studied five clones of E. urophylla $x$ E. grandis and found mean density values ranging from 0.429 to 0.471 $\mathrm{g} \mathrm{cm}^{-3}$.

The trees grown in the integrated system had higher wood density than those grown in the traditional system. This can

Table 3. Average values of canopy projection of Eucalyptus grandis $x$ Eucalyptus urophylla trees grown in monoculture and iCLF systems in Sinop, Mato Grosso, Brazil.

\begin{tabular}{cccccc}
\hline \multirow{2}{*}{ System } & \multicolumn{5}{c}{ Tree canopy projection $(\mathbf{m})$} \\
\cline { 2 - 6 } & North & Este & South & West & Average \\
\hline Monoculture & $2.07 \pm 0.34 \mathrm{a}$ & $1.36 \pm 0.50 \mathrm{a}$ & $1.16 \pm 0.45 \mathrm{~b}$ & $1.83 \pm 0.53 \mathrm{a}$ & $1.60 \pm 0.37 \mathrm{a}$ \\
iCLF & $2.28 \pm 0.85 \mathrm{a}$ & $0.95 \pm 0.50 \mathrm{~b}$ & $2.05 \pm 1.08 \mathrm{a}$ & $1.28 \pm 0.31 \mathrm{~b}$ & $1.64 \pm 0.32 \mathrm{a}$ \\
\hline
\end{tabular}

Means followed by the same letter in the columns do not differ statistically, according to the Tukey test at $5 \%$ significance. 
Table 4. Average values of canopy projection measured for the iCLF system of Eucalyptus grandis x Eucalyptus urophylla in Sinop, Mato Grosso, Brazil.

\begin{tabular}{cccccc}
\hline \multirow{2}{*}{ Exposure } & \multicolumn{5}{c}{ Tree canopy projection $(\mathrm{m})$} \\
\cline { 2 - 6 } & North & Este & South & West & Average \\
\hline Central & $1.76 \pm 0.31 \mathrm{~b}$ & $1.03 \pm 0.34 \mathrm{a}$ & $1.63 \pm 0.21 \mathrm{~b}$ & $1.21 \pm 0.18 \mathrm{~b}$ & $1.41 \pm 0.12 \mathrm{~b}$ \\
North & $3.24 \pm 0.72 \mathrm{a}$ & $0.72 \pm 0.26 \mathrm{a}$ & $1.50 \pm 0.10 \mathrm{~b}$ & $1.04 \pm 0.25 \mathrm{~b}$ & $1.63 \pm 0.17 \mathrm{ab}$ \\
South & $1.83 \pm 0.41 \mathrm{~b}$ & $1.09 \pm 0.71 \mathrm{a}$ & $3.02 \pm 1.44 \mathrm{a}$ & $1.59 \pm 0.23 \mathrm{a}$ & $1.88 \pm 0.40 \mathrm{a}$ \\
\hline
\end{tabular}

Means followed by the same letter in the columns do not differ statistically, according to the Tukey test at $5 \%$ significance.

Table 5. Pilodyn penetration capacity $(\mathrm{mm})$ of Eucalyptus grandis $x$ Eucalyptus urophylla trees grown in monoculture and iCLF systems in Sinop, Mato Grosso, Brazil.

\begin{tabular}{cccccc}
\hline \multirow{2}{*}{ System } & \multicolumn{5}{c}{ Pilodyn penetration $(\mathrm{mm})$} \\
\cline { 2 - 6 } & North & Este & South & West & Average \\
\hline Monoculture & $19.75 \pm 0.87 \mathrm{a}$ & $20.33 \pm 1.07 \mathrm{a}$ & $20.92 \pm 1.24 \mathrm{a}$ & $20.92 \pm 1.31 \mathrm{a}$ & $20.48 \pm 0.81 \mathrm{a}$ \\
iCLF & $18.03 \pm 1.56 \mathrm{~b}$ & $18.19 \pm 1.31 \mathrm{~b}$ & $18.39 \pm 1.52 \mathrm{~b}$ & $18.25 \pm 1.87 \mathrm{~b}$ & $18.22 \pm 1.37 \mathrm{~b}$ \\
\hline
\end{tabular}

Means followed by the same letter in the columns do not differ statistically, according to the Tukey test at $5 \%$ significance.

Table 6. Density estimated with a Pilodyn meter $\left(\mathrm{g} \mathrm{cm}^{-3}\right)$ of Eucalyptus grandis $x$ Eucalyptus urophylla trees grown in monoculture and iCLF systems in Sinop, Mato Grosso, Brazil.

\begin{tabular}{cccccc}
\hline \multirow{2}{*}{ System } & \multicolumn{5}{c}{ Density $\left(\mathrm{g} \mathrm{cm}^{-3}\right)$} \\
\cline { 2 - 6 } & North & Este & South & West & Average \\
\hline Monoculture & $0.412 \pm 0.012 \mathrm{~b}$ & $0.405 \pm 0.015 \mathrm{~b}$ & $0.397 \pm 0.017 \mathrm{~b}$ & $0.423 \pm 0.018 \mathrm{~b}$ & $0.403 \pm 0.011 \mathrm{~b}$ \\
iCLF & $0.436 \pm 0.021 \mathrm{a}$ & $0.434 \pm 0.018 \mathrm{a}$ & $0.431 \pm 0.021 \mathrm{a}$ & $0.490 \pm 0.025 \mathrm{a}$ & $0.433 \pm 0.019 \mathrm{a}$ \\
\hline
\end{tabular}

Means followed by the same letter in the columns do not differ statistically, according to the Tukey test at $5 \%$ significance.

be explained by the fact that these trees are more subject to the action of the weather, especially the action of winds. Wood in these conditions tends to have a higher percentage of gelatinous fibers, of slightly higher density due to the occurrence of driftwood (Washusen et al., 2001; Vidaurre et al., 2013). In addition, the passage of animals in this system causes frequent contact with trees during grazing. This causes the trees to produce a higher percentage of reaction wood (Ferreira et al., 2020).

\section{Nondestructive analysis - Growth stress}

LRS levels were similar between cultivation systems for most of the evaluated exposures. The only exception was the East exposure, where iCLF showed greater deformations when compared to the monoculture. Regarding the average behavior, the monoculture trees also showed lower values than those of the iCLF system (Table 7).

When studying LRS in a monoculture system of Eucalyptus spp. at different ages, Lima et al. (2004) found mean values of $0.071 \mathrm{~mm}$, indicating less deformation compared to the average of that study. Similarly, Muneri et al. (1999), when evaluating the intensity of growth stresses through LRD, obtained mean values of $0.077 \mathrm{~mm}$ in a monoculture stand of Eucalyptus cloeziana at 4 years of age.
The average LRS values found in our study were clearly greater than the values reported by the authors mentioned above. This fact can be attributed to differences in species, location, age and incidence of winds, which can influence the occurrence of this metric.

The results observed in the iCLF system in the trees with different exposures did not show significant differences ( $p>$ 0.05 ) (Table 8). This indicates that the locations of the trees in relation to their exposure in the row do not interfere with growth stresses.

In the iCLF system, on average the total height and the diameter were greater in relation to the monoculture stand. The total volume of wood produced in the homogeneous system was higher than in the iCLF system, while the individual volume of trees was smaller. We also observed that on average, the highest densities and growth stresses were observed in trees in the integrated system, for all exposures. In analyzing Grevillea robusta, Martins et al. (2002) found that trees planted in single lines or on borders received a greater amount of light on the side of the canopy, so they ended up having the greatest development on the face exposed to sunlight, resulting in a shaft with asymmetric cross section and consequently low wood quality due to the formation of reaction wood.

Table 7. Longitudinal residual strain (LRS) of Eucalyptus grandis $x$ Eucalyptus urophylla trees grown in monoculture and iCLF systems in Sinop, Mato Grosso, Brazil.

\begin{tabular}{cccccc}
\hline \multirow{2}{*}{ System } & North & Este & Songitudinal residual strain $(\mathrm{mm})$ & West & Average \\
\cline { 2 - 6 } & $0.121 \pm 0.056 \mathrm{a}$ & $0.109 \pm 0.041 \mathrm{~b}$ & $0.132 \pm 0.076 \mathrm{a}$ & $0.095 \pm 0.061 \mathrm{a}$ & $0.114 \pm 0.026 \mathrm{~b}$ \\
\hline Monoculture & $0.172 \pm 0.165 \mathrm{a}$ & $0.155 \pm 0.067 \mathrm{a}$ & $0.133 \pm 0.078 \mathrm{a}$ & $0.128 \pm 0.071 \mathrm{a}$ & $0.147 \pm 0.051 \mathrm{a}$ \\
\hline iCLF &
\end{tabular}

Means followed by the same letter in the columns do not differ statistically, according to the Tukey test at $5 \%$ significance. 
Table 8. Longitudinal residual strain (LRS) for the iCLF system of Eucalyptus grandis x Eucalyptus urophylla, in Sinop, Mato Grosso, Brazil.

\begin{tabular}{cccccc}
\hline \multirow{2}{*}{ Exposure } & \multicolumn{5}{c}{ Longitudinal residual strain $(\mathrm{mm})^{\text {NS }}$} \\
\cline { 2 - 6 } & North & Este & South & West & Average \\
\hline Central & $0.19 \pm 0.15$ & $0.16 \pm 0.06$ & $0.15 \pm 0.11$ & $0.15 \pm 0.07$ & $0.16 \pm 0.04$ \\
North & $0.14 \pm 0.06$ & $0.15 \pm 0.09$ & $0.12 \pm 0.06$ & $0.13 \pm 0.08$ & $0.13 \pm 0.04$ \\
South & $0.19 \pm 0.24$ & $0.24 \pm 0.06$ & $0.13 \pm 0.06$ & $0.10 \pm 0.05$ & $0.14 \pm 0.07$ \\
\hline
\end{tabular}

Ns: no statistical differences were detected $(p>0.05)$.

\section{Conclusions}

The trees of the eucalyptus hybrid studied here (Eucalyptus grandis $x$ Eucalyptus urophylla) grown in the iCLF system had higher wood density than those grown in the homogeneous stand.

The longitudinal residual deformations, resulting from growth stresses, were higher in trees grown in the iCLF system.

\section{Acknowledgements}

This study was financed by Brazilian agencies National Council for Scientific and Technological Development (CNPq) and Office to Coordinate Improvement of University Personnel (CAPES).

\section{Literature Cited}

Alvarenga, R. C.; Silva, V. P.; Gontijo Neto, M. M.; Vianc, M. C. M.; Vilela, M. Sistema integração lavoura-pecuária-floresta: condicionamento do solo e intensificação da produção de lavouras. Informe Agropecuário, v. 31, n. 257, p. 59-67, 2010. https://ainfo.cnptia.embrapa.br/digital/bitstream/ item/32650/1/Sistema-de-integracao-Lavoura-PecuariaFloresta.pdf. 05 Nov. 2019.

Alvares, C. A.; Stape, J. L.; Sentelhas, P. C.; Gonçalves, J. L. M.; Sparovek, G. Köppen's climate classific ation map for Brazil. Meteorologische Zeitschrift, v. 22, n. 6, p. 711-728, 2013. http:// dx.doi.org/10.1127/0941-2948/2013/0507.

Balbino, L. C.; Cordeiro, L. A. M.; Silva, V. P.; Moraes, A.; Martínez, G. B.; Alvarenga, R. C.; Kichel, A. N.; Fontaneli, R. S.; Santos, H. P.; Franchini, J. C.; Galerani, P. R. Evolução tecnológica e arranjos produtivos de sistemas de integração lavoura-pecuáriafloresta no Brasil. Pesquisa Agropecuária Brasileira, Brasília, v. 46, n. 10 , p. $1-12$, 2011. https://doi.org/10.1590/S0100204X2011001000001.

Beltrame, R.; Lazarotto, M.; Haselein, C. R.; Santini, E. J.; Schneider, P. R.; Aguiar, A. M. Determinação das deformações residuais longitudinais decorrentes das tensões de crescimento em Eucalyptus spp. Ciência Florestal, v. 22, n. 2, p. 343-351, 2012. https://doi.org/10.5902/198050985741.

Boton, D.; Fonseca, R. C.; Mota, L. L.; Silva, W. C.; Souza, A. P. Caracterização da Velocidade e Direção Predominante dos Ventos na Região de Sinop, Mato Grosso. Scientific Electronic Archives, v. 3, n. 2, p. 49-54, 2013. https://sea.ufr.edu.br/index. php?journal=SEA\&page $=$ article $\& o p=v i e w \&$ path $\% 5 B \% 5 D=41$. 12 Mar. 2020.
Braz, R. L.; Nutto, L.; Mattos, J. L. M. Efeito da poda sobre a qualidade da madeira de Eucalyptus dunnii, Eucalyptus grandis e Eucalyptus saligna. Scientia Forestalis, v. 45, n. 114, p. 261-274, 2017. https://doi.org/10.18671/scifor.v45n114.

Ferreira, M. D.; Melo, R. R.; Tonini, E.; Pimenta, A. S.; Gatto, D. A.; Beltrame, R.; Stangerlin, D. M. Physical-mechanical properties of wood from a eucalyptus clone planted in an integrated croplivestock-forest system. International Wood Products Journal, v. 11, n. 1, p. 1-8, 2020. https://doi.org/10.1080/20426445.2019.1706137

Gregolin, F. S. Estoques de carbono e nitrogênio do solo manejado em sistemas de integração. Sinop: Universidade Federal de Mato Grosso, 2017. 60p. Dissertação Mestrado. http://www.alice. cnptia.embrapa.br/alice/handle/doc/1081555. 12 Out. 2019.

Hsing, T. Y.; Paula, N. F.; Paula, R. C. Características dendrométricas, químicas e densidade básica da madeira de híbridos de Eucalyptus grandis x Eucalyptus urophylla. Ciência Florestal, v. 26, n. 1, p. 273-283, 2016. https://doi.org/10.5902/1980509821119.

Lemmon, P. E. A new instrument for measuring forest overstory density. Journal of Forestry, v. 55, n. 9, p. 667-668, 1957.

Lima, J. T.; Trugilho, P. F.; Rosado, S. C. S.; Cruz, C. R. Deformações residuais longitudinais decorrentes de tensões de crescimento em eucaliptos e suas associações com outras propriedades. Revista Árvore, v. 28, n. 1, p. 107-116, 2004. https://doi. org/10.1590/S0100-67622004000100014.

Lucas, M. A. K.; Perske, R. C. F.; Souza, R. V.; Pimentel, D. C. C. Sistema silvipastoril na Região da Campanha do Rio Grande do Sul. Bagé: Embrapa Pecuária Sul, 2015. 23p. (Embrapa Pecuária Sul. Documentos, 142). https://ainfo.cnptia.embrapa.br/digital/ bitstream/item/129414/1/Sistema-Silvipastori-pdfl.pdf. 29 Mar. 2020.

Martins, E. G.; Neves, E. J. M.; Ferreira, C. A.; Shimizu, J. Y. Desempenho de procedências de grevílea nos estados do Paraná e São Paulo. In: Congresso Brasileiro de Sistemas Agroflorestais, 4., 2002, Ilhéus. Anais... Ilhéus, CEPLAC; UESC, 2002. https://ainfo.cnptia. embrapa.br/digital/bitstream/item/97061/1/1011desempenho. pdf. 19 Mar. 2020.

Mascarenhas, A. R. P.; Sccoti, M. S. V.; Melo, R. R.; Corrêa, F. L. O.; Souza, E. F. M.; Andrade, A. A.; Bergamin, A. C.; Müller, M. W. Atributos físicos e estoques de carbono do solo sob diferentes usos da terra em Rondônia, Amazônia Sul-Ocidental. Pesquisa Florestal Brasileira, v. 37, n. 89, p. 19-27, 2017. https://doi. org/10.4336/2017.pfb.37.89.1295

Matias, S. V. B. G. Desempenho silvicultural e qualidade da madeira de clones de Eucalyptus em sistemas de integração lavoura pecuária floresta. Lavras: Universidade Federal de Lavras, 2016. 89p. Tese Doutorado. http://repositorio.ufla.br/jspui/handle/1/10805. 03 Mar. 2020. 
Muneri, A.; Legate, W.; Palmer, G. Relationships between surface growth strain and some tree wood and sawn timber characteristics of Eucalyptus cloeziana. Southern African Forestry Journal, v. 187, n. 1, p. 41-49, 1999. https://doi.org/10.1080/102 95925.1999.9631241.

Oliveira, F. L. R.; Cabacinha, C. D.; Santos, L. D. T.; Barroso, D. G.; Santos Júnior, A.; Brant, M. C.; Sampaio, R. A. Crescimento inicial de eucalipto e acácia, em diferentes arranjos de integração lavoura-pecuária-floresta. Cerne, v. 21, n. 2, p. 227-233, 2015. https://doi.org/10.1590/010477602015210 21489.

Oliveira, T. K.; Macedo, R. L. G.; Venturin, N.; Higashikawa, E. M. Desempenho silvicultural e produtivo de eucalipto sob diferentes arranjos espaciais em sistema agrossilvipastoril. Pesquisa Florestal Brasileira, v. 29, n. 60, p. 01-09, 2009. https://doi. org/10.4336/2009.pfb.60.01.
Pereira, J. C. Características da madeira de algumas espécies de eucalipto plantadas no Brasil. Colombo: Embrapa Florestas, 2000. 113 p. (Embrapa Florestas. Documentos, 38). https://www.agencia.cnptia. embrapa.br/recursos/doc38ID-Mw8eMekWla.pdf. 22 Mar. 2020.

Radomski, M. I.; Ribaski, J. Excentricidade da medula em Grevillea robusta e Corymbia citriodora cultivados em sistema silvipastoril. Colombo: Embrapa Florestas, 2010. 48p. (Embrapa Florestas. Documentos, 248). https://ainfo.cnptia.embrapa.br/digital/ bitstream/item/28889/1/CT248.pdf. 31 Mar. 2020.

Vidaurre, G. B.; Lombardi, L. R.; Nutto, L.; França, F. J. N.; Oliveira, J. T. S.; Arantes, M. D. C. Propriedades da madeira de reação. Floresta Ambiente, v. 20, n. 1, p. 26-37, 2013. https://doi.org/10.4322/floram.2012.041.

Washusen, R.; Ades, P.; Evans, R.; Ilic, J.; Vinden, P. Relationships between density, shrinkage, extractives content and microfibril angle in tension wood from three provenances of 10 -year-old Eucalyptus globulus Labill. Holzforschung, v. 55, n. 2, p. 176-182, 2001. https://doi.org/10.1515/HF.2001.029. 